\title{
Sodium and potassium intakes in Ireland
}

\author{
BY ALBERT FLYNN, COLETTE SHORTT AND \\ PATRICK A. MORRISSEY \\ Department of Nutrition, University College, Cork, Irish Republic
}

There is considerable interest in the intakes of sodium and potassium, particularly in relation to the significance of these nutrients in the control of blood pressure. In the present review a number of aspects of $\mathrm{Na}$ and $\mathrm{K}$ are addressed. Methodology for assessment of intakes is described and findings for dietary intakes and dietary sources in Ireland are presented and compared with studies in the UK. The health significance of $\mathrm{Na}$ and $\mathrm{K}$ intakes is considered and the present status of dietary guidelines for $\mathrm{Na}$ and $\mathrm{K}$ is discussed in the light of recent large epidemiological studies on the relationship of dietary intakes of these elements to blood pressure.

\section{ASSESSMENT OF Na AND K INTAKES}

Assessment of $\mathrm{Na}$ intake of free-living individuals by dietary record methods is unreliable for two reasons. Information on the average $\mathrm{Na}$ contents of foods do not reflect the very wide variation in the $\mathrm{Na}$ content of any given food type (Paul \& Southgate, 1978) and accurate measurement of discretionary salt intake (i.e. salt added to food during preparation and at table) is very difficult. The most widely used method for estimating $\mathrm{Na}$ intake is from $24 \mathrm{~h}$ urinary $\mathrm{Na}$ excretion (Flynn, 1984). This is based on the observation that except under exceptional circumstances (e.g. excessive sweat loss, vomiting or diarrhoea), over $95 \%$ of dietary $\mathrm{Na}$ is excreted in urine (Schachter et al. 1980).

There is a large intra-individual (i.e. day-to-day) variation in $24 \mathrm{~h}$ urinary $\mathrm{Na}$ excretion (Liu et al. 1979; Joossens et al. 1980; Shortt et al. 1988a) and the implication of this is that assessment of the usual $\mathrm{Na}$ intake of an individual requires that urine collections be obtained for a number of days. It has been estimated (Liu et al. 1979) that seven to fourteen $24 \mathrm{~h}$ urine collections are necessary to characterize an individual's usual $\mathrm{Na}$ intake. However, mean $24 \mathrm{~h}$ urinary $\mathrm{Na}$ excretion based on a single $24 \mathrm{~h}$ urine collection for each individual in a group provides a good estimate of mean daily $\mathrm{Na}$ intake of that group (Joossens \& Geboers, 1984). In addition, the sample size required for the estimation of the group mean $24 \mathrm{~h}$ urinary $\mathrm{Na}$ excretion can be determined from data on intra-individual and inter-individual variation (Van Staveren et al. 1982; Shortt et al. 1988a).

Dietary record methods are more reliable for assessment of $\mathrm{K}$ intake than for $\mathrm{Na}$ intake. However, $24 \mathrm{~h}$ urinary $\mathrm{K}$ excretion is widely used as an estimate of daily $\mathrm{K}$ intake. This is based on the observation that there is a very close relationship between 24 $\mathrm{h}$ urinary $\mathrm{K}$ excretion and daily $\mathrm{K}$ intake (Mathers, 1988). The large intra-individual variation in $24 \mathrm{~h}$ urinary $\mathrm{K}$ excretion (Shortt et al. 1988a) requires that a large number of urine collections must be made in order to assess the usual daily $\mathrm{K}$ intake of an individual. However, mean $24 \mathrm{~h}$ urinary $\mathrm{K}$ excretion based on a single $24 \mathrm{~h}$ urine collection for each individual in a group provides a good estimate of mean daily $\mathrm{K}$ intake of that group. 
The $24 \mathrm{~h}$ urine collection method has been described by Shortt et al. (1987a). Each subject is provided with a large (approximately 2.5 litre) plastic container containing preservative (e.g. $10 \mathrm{ml}$ glacial acetic acid containing $250 \mathrm{mg}$ thymol) and given detailed written and oral instructions. Individuals are required to report the time of the first and last voiding of urine and to report whether or not a complete collection was made. In addition, sex, age, height, weight and social class are recorded.

Given the nature of this method it is not surprising that individuals do not always comply with instructions and over- and under-collection of urine can occur. Indeed, the single greatest difficulty with this method is in assessing the completeness of $24 \mathrm{~h}$ urine collection. Self-reporting is not reliable as a means of assessing completeness of collection, but nevertheless it is very useful as it allows the exclusion of samples freely admitted to being incomplete (Knuiman et al. 1986b).

Ever since Folin (1905) reported that $24 \mathrm{~h}$ creatinine excretion is constant in individuals on varied diets, creatinine has been used as a check for completeness of urine collections. Joossens \& Geboers (1984) have proposed that completeness of $24 \mathrm{~h}$ urine collection for individuals can be assessed by a creatinine index, i.e. the ratio, observed creatinine excretion:that expected for sex and body-weight. However, while daily urine creatinine excretion is determined largely by muscle mass (Heymsfield et al. 1983), it is also influenced by a number of other factors including strenuous exercise, the stage of the menstrual cycle in women, age, severe emotional stress, acute infection, fever and trauma, and renal insufficiency (Heymsfield et al. 1983; Fuller \& Elia, 1988). It is also influenced by dietary protein, creatine and creatinine and it has been found that changing from a meat-free to a meat-based diet rapidly results in a $10-30 \%$ increase in urinary creatinine excretion (Bleiler \& Schedl, 1972). There is also a considerable variation between individuals in $24 \mathrm{~h}$ urinary creatinine excretion. Bingham \& Cummings (1983) have shown that creatinine excretion of one individual can be almost double that of another when expressed on a fat-free-mass basis. They estimated that up to $40 \%$ of urine could be lost in a $24 \mathrm{~h}$ period, yet the remainder would still give a creatinine value within the normal range. Creatinine is, therefore, unsuitable as a means of assessing the completeness of $24 \mathrm{~h}$ urine collection in an individual, and is useful only in detecting gross errors in collection (Bingham \& Cummings, 1985; Knuiman et al. 1986a).

Bingham \& Cummings (1983) have proposed the use of $p$-aminobenzoic acid (PABA) as a marker for completeness of $24 \mathrm{~h}$ urine collection in individuals. PABA capsules are ingested by subjects during the collection period and completeness of urine collection determined from recovery of PABA in urine. While this method is more reliable than creatinine for assessing completeness in individuals, it is suitable only for detecting under-collection and does not give any indication of over-collection.

While completeness of $24 \mathrm{~h}$ urine collection is very difficult to assess for individuals, the mean completeness of collection for a group can be assessed by comparison of the observed mean $24 \mathrm{~h}$ urinary creatinine excretion for the group with suitable reference values. For example, Joossens et al. (1980) have developed a polynomial equation for calculating reference values for creatinine excretion which takes age, height, weight, sex and social class into account, based on creatinine excretions in a large number of free-living individuals in Belgium. Reliable reference values for average $24 \mathrm{~h}$ urinary creatinine excretion of male $(1.82 \mathrm{~g})$ and female $(1.26 \mathrm{~g})$ adults are available from a study in Cambridgeshire, England (Bingham \& Cummings, 1985; Williams \& Bingham, 1986; Bingham et al. 1988) in which $24 \mathrm{~h}$ urinary creatinine output was determined in a 
randomly selected population sample of seventy-one males and fifty-one females whose collections were carefully monitored for completeness using PABA as a marker.

\section{Na AND K INTAKES IN IRELAND AND UK}

A study of $\mathrm{Na}$ and $\mathrm{K}$ intakes of selected groups in Cork was undertaken (Shortt et al. 1987a) as part of the EURONUT SALT Project involving eleven European centres. A total of 132 individuals between the ages of 19 and 60 years living in Cork city were recruited and a single $24 \mathrm{~h}$ urine collection obtained from each. Participants consumed their usual diet during the collection period and were not aware that there was a particular interest in $\mathrm{Na}$ or $\mathrm{K}$ intake. Height and weight were measured and a questionnaire was completed by each subject. The groups consisted of civil servants, army personnel, student nurses and laboratory workers. These groups have been classified as social group 2 in Ireland (Central Statistics Office, 1982). The mean age of the female group ( $n$ 62) was 24 (range $21-49$ ) years, while mean age of the males was 32 (range 19-59) years.

Completeness of $24 \mathrm{~h}$ urine collection in individuals is shown in Table 1 . For females forty-nine of sixty-one subjects reported collection to be complete and one of these was adjudged to be over-collected on the basis of the creatinine index. Fifty of sixty-six males reported collection as complete and four were adjudged as under-collected on the basis of the creatinine index. Only those collections adjudged to be complete by both self-reporting and by the creatinine index were included in the estimation of mean $\mathrm{Na}$ and $\mathrm{K}$ intakes. It is interesting to note that nine of twelve collections for females and five of sixteen collections for males which were reported as being incomplete would not have been detected as incomplete by the creatinine index method, indicating that this method is not a sensitive indicator of completeness in individuals.

Mean $24 \mathrm{~h}$ creatinine excretion of males ( $1.67 \mathrm{~g})$ and females $(1.25 \mathrm{~g})$ (Table 2$)$ were very similar to reference values calculated using the equation of Joossens et al. (1980) (1.77 and $1.28 \mathrm{~g}$ respectively) and also to reference values of Bingham \& Cummings (1985) ( 1.82 and $1.26 \mathrm{~g}$ respectively) indicating that mean completeness of $24 \mathrm{~h}$ urine collection for the groups was good.

The average $24 \mathrm{~h} \mathrm{Na}$ excretion for complete collections in this study (Table 2) was $165.6 \mathrm{mmol}$ (equivalent to $3.81 \mathrm{~g} \mathrm{Na}$ or $9.7 \mathrm{~g}$ sodium chloride) for males and $133.8 \mathrm{mmol}$ (equivalent to $3.08 \mathrm{~g} \mathrm{Na}$ or $7.8 \mathrm{~g} \mathrm{NaCl}$ ) for females (Table 2). The pooled mean $24 \mathrm{~h}$ urinary $\mathrm{Na}$ excretion of males and females was $150 \mathrm{mmol}$ (equivalent to $3.45 \mathrm{~g} \mathrm{Na}$ or 8.8 $\mathrm{g} \mathrm{NaCl}$ ). There are few values for $\mathrm{Na}$ intakes of groups in the Irish population with which these results can be compared. Connolly et al. (1980) estimated the mean daily $\mathrm{Na}$ intake from $3 \mathrm{~d}$ weighed food records in selected adults (thirty-six male, thirty-five female) living in a semi-rural area. Average daily $\mathrm{Na}$ intakes were $3.74 \mathrm{~g}(9.5 \mathrm{~g} \mathrm{NaCl})$ and $2.98 \mathrm{~g}$ $(7.8 \mathrm{~g} \mathrm{NaCl})$ for males and females respectively, with a pooled mean of $3.36 \mathrm{~g}(8.9 \mathrm{~g}$ $\mathrm{NaCl}$. However, this did not include discretionary salt intake and, as indicated earlier, estimation of $\mathrm{Na}$ intake from food records using tables of food composition is not reliable.

Madden et al. (1983) reported that the average $24 \mathrm{~h}$ urinary excretion of twenty-five male and twenty-six female students, aged 19-21 years, living in Cork city, were $4.76 \mathrm{~g}$ $(12.2 \mathrm{~g} \mathrm{NaCl})$ and $3.08 \mathrm{~g}(7.9 \mathrm{~g} \mathrm{NaCl})$ respectively, with a pooled mean of $3.9 \mathrm{~g}(10.0 \mathrm{~g}$ $\mathrm{NaCl}$ ). However, completeness of $24 \mathrm{~h}$ urine collection was not assessed in this study. 
Table 1. Comparison of self-reported completeness of $24 \mathrm{~h}$ urine collection with completeness as assessed by the creatinine index method*

\begin{tabular}{lcccc}
\hline \hline & \multicolumn{3}{c}{ Creatinine index $\dagger$} \\
\cline { 3 - 5 } Urine collections & No. of collections & $<60 \%$ & $60-140 \%$ & $>140 \%$ \\
\hline Reported as complete & & & & \\
$\quad$ Females & 49 & 0 & 48 & 1 \\
$\quad$ Males & 50 & 4 & 46 & 0 \\
Reported as incomplete & & & & \\
$\quad$ Females & 12 & 3 & 9 & 0 \\
$\quad$ Males & 16 & 5 & 11 & 0 \\
\hline \hline
\end{tabular}

* Shortt et al. (1987a).

$\dagger$ Joossens \& Geboers (1984).

Table 2. Excretion of sodium, potassium and creatinine in complete $24 \mathrm{~h}$ urine collections* (Mean values and standard deviations)

\begin{tabular}{|c|c|c|c|}
\hline & $\underset{(\mathrm{mmol} / 24 \mathrm{~h})}{\mathrm{Na}}$ & $\underset{(\mathrm{mmol} / 24 \mathrm{~h})}{\mathrm{K}}$ & $\begin{array}{c}\text { Creatinine } \\
(\mathrm{g} / 24 \mathrm{~h})\end{array}$ \\
\hline \multicolumn{4}{|c|}{ Females $(n 48)$} \\
\hline Mean & 133.8 & $60 \cdot 1$ & 1.25 \\
\hline SD & $42 \cdot 6$ & 21.5 & $0 \cdot 22$ \\
\hline Range & $63 \cdot 2-275 \cdot 4$ & $17 \cdot 4-106 \cdot 4$ & $0.85-1.84$ \\
\hline \multicolumn{4}{|c|}{ Males $(n 46)$} \\
\hline Mean & $165 \cdot 6$ & $79 \cdot 1$ & 1.67 \\
\hline SD & 63.6 & $31 \cdot 1$ & 0.35 \\
\hline Range & $42 \cdot 4-351 \cdot 8$ & $18 \cdot 0-155 \cdot 0$ & $0.85-2.4$ \\
\hline
\end{tabular}

* Shortt et al. (1987a).

Data for $\mathrm{Na}$ intakes of selected groups in Cork are similar to most recent data for randomly selected population samples in Great Britain and Northern Ireland (Table 3). Mean $24 \mathrm{~h}$ urinary $\mathrm{Na}$ excretion was estimated in a randomly selected group of seventy-one males and fifty-one females in Cambridgeshire in whom urine collections were carefully monitored for completeness using the PABA method (Bingham \& Cummings, 1985; Williams \& Bingham, 1986). Average $24 \mathrm{~h}$ urinary $\mathrm{Na}$ excretion was $3.96 \mathrm{~g}(10.0 \mathrm{~g} \mathrm{NaCl})$ for males and $2.94 \mathrm{~g}(7.5 \mathrm{~g} \mathrm{NaCl})$ for females with a pooled mean of $3.45 \mathrm{~g} \mathrm{Na}(8.8 \mathrm{~g} \mathrm{NaCl})$. Similar values were found for mean $24 \mathrm{~h}$ urine $\mathrm{Na}$ excretion in groups of randomly selected adults in Belfast, South Wales and Birmingham in the Intersalt Study (Table 3), but the values reported for randomly selected adults in the Scottish Heart Health Study (Smith et al. 1988) were somewhat higher (Table 3).

It is noteworthy that the measured mean $\mathrm{Na}$ intake of adults in the British Isles reported in Table 3 are all significantly lower than the value of $12 \mathrm{~g} \mathrm{NaCl}$ used in the NACNE Report (National Advisory Committee on Nutrition Education, 1983) and by the Irish Food Advisory Committee (Food Advisory Committee, 1984a,b) in promul- 
Table 3. Mean $24 \mathrm{~h}$ urine sodium and potassium excretion ( $U_{N a}$ and $U_{K}$ respectively) of adults in Ireland and $U K$

\begin{tabular}{lccl}
\hline Location & $\begin{array}{c}\mathrm{U}_{\mathrm{Na}} \\
(\mathrm{mmol} / 24 \mathrm{~h})\end{array}$ & $\begin{array}{c}\mathrm{U}_{\mathrm{K}} \\
(\mathrm{mmol} / 24 \mathrm{~h})\end{array}$ & \multicolumn{1}{c}{ Reference } \\
\hline Scotland & 168 & 61 & Smith et al. (1988) \\
Birmingham & 153 & 63 & Intersalt Cooperative Research Group (1988) \\
S. Wales & 152 & 63 & Intersalt Cooperative Research Group (1988) \\
Belfast & 151 & 75 & Intersalt Cooperative Research Group (1988) \\
Cambridgeshire & 150 & 66 & Bingham \& Cummings (1985) \\
Cork & 150 & 70 & Shortt et al. (1987a) \\
\hline \hline
\end{tabular}

Table 4. Dietary sources of sodium and potassium in Ireland and UK

\begin{tabular}{lccccc}
\hline & \multicolumn{2}{c}{$\mathrm{Na}(\%$ total $)$} & & \multicolumn{2}{c}{$\mathrm{K}(\%$ total $)$} \\
\cline { 2 - 3 } \cline { 5 - 6 } Food group & Ireland* & UK ${ }^{*}$ & & Ireland $^{*}$ & UK $\neq$ \\
\hline Cereal (bread) & $42(27)$ & 41 & & $15(7)$ & 16 \\
Meat (and eggs) & 22 & 23 & & 10 & 14 \\
Dairy & 21 & 20 & & 29 & 24 \\
Fruit/vegetables & 4 & 14 & & 32 & 40 \\
Other & 11 & 2 & & 14 & 6 \\
Total & 100 & 100 & & 100 & 100 \\
\hline \hline
\end{tabular}

* Downey et al. (1982), excluding salt used in the home.

$\dagger$ Bull \& Buss (1980a), excluding salt used at table but including salt used in cooking.

$\ddagger$ Bull \& Buss $(1980 b)$.

gating dietary guidelines for salt reduction for the general population. Indeed, the measured values are all very close to the target value of $9 \mathrm{~g} \mathrm{NaCl}$ recommended in these reports. The COMA Report (Department of Health and Social Security, 1984) estimated the average daily salt intake in Britain to be $7-10 \mathrm{~g}$, and this appears to be close to the most recently reported values.

It would appear that the marked divergence in estimates of salt intake may arise from overestimation of salt used in the home (James et al. 1987). Sanchez-Castillo et al. (1987) determined salt intake in a randomly selected population living in Cambridgeshire, UK. Using lithium as a marker in table salt they showed that $15 \%$ of total salt intake is derived from salt used in cooking $(6 \%)$ and at table $(9 \%)$. This is considerably lower than previous estimates which suggested that about one-third of $\mathrm{Na}$ intake was derived from discretionary salt use (Upton \& Gibney, 1977; Bull \& Buss, 1980a).

The contribution of different food groups to $\mathrm{Na}$ intake in Ireland and the UK is outlined in Table 4. The Irish findings (Downey et al. 1982) are based on the study of Connolly et al. (1980) of $\mathrm{Na}$ intakes in selected individuals using $3 \mathrm{~d}$ weighed food records, while the UK values (Bull \& Buss, 1980a) are based on analysis of 'total diet' samples from six areas in the UK and include salt added in food preparation but not that added at table. The results indicate that the cereals group is the single greatest source of $\mathrm{Na}$ in both the Irish and UK diets, contributing over $40 \%$ of total $\mathrm{Na}$ intake. Most of this 
is obtained from bread. Bull \& Buss (1980a) have estimated that about $86 \%$ of total Na intake from foods was derived from processed foods, and most of this comes from salt added during processing.

Thus, there is an apparent conflict between dietary recommendations to reduce salt intake and increase cereal consumption (National Advisory Committee on Nutrition Education, 1983; Department of Health and Social Security, 1984; Food Advisory Committee, 1984a,b). Furthermore, the other food groups which make a significant contribution to $\mathrm{Na}$ intake, i.e. meat and dairy products, also make a major contribution to the intake of essential nutrients in the Irish diet (Upton \& Gibney, 1987). Given these considerations it would seem that a reduction in the quantity of salt added to foods during processing would be the most effective and nutritionally most prudent means of reducing average $\mathrm{Na}$ intake of the population. Strategies for reducing the average $\mathrm{Na}$ intake of the population will not be successful unless food manufacturers can be persuaded to reduce the salt content of foods, particularly foods that are commonly consumed, e.g. bread. Salt serves many functions in processed foods (Institute of Food Technologists, 1980), including flavour enhancement and preventing the growth of spoilage micro-organisms. Food manufacturers may need to be convinced that there is sufficient evidence of a clear benefit to public health from reducing the average $\mathrm{Na}$ intake of the population before they undertake a programme of salt reduction in processed foods.

The average $24 \mathrm{~h} \mathrm{~K}$ excretion in the present study was $79.1 \mathrm{mmol}$ for males and 60.5 $\mathrm{mmol}$ for females, with a pooled mean of $69.8 \mathrm{mmol}$. There are few values for $\mathrm{K}$ intakes of groups in Ireland. Madden et al. (1983) reported $24 \mathrm{~h}$ urinary $\mathrm{K}$ excretion for young male $(3 \cdot 1 \mathrm{~g})$ and female $(2 \cdot 2 \mathrm{~g})$ adults living in Cork city; however, completeness of urine collection was not assessed. Downey et al. (1982) estimated average $\mathrm{K}$ intakes of $3.9 \mathrm{~g}$ for male and $3.2 \mathrm{~g}$ for female adults, living in a semi-rural area in Cork, using $3 \mathrm{~d}$ weighed food records. The value for $24 \mathrm{~h} \mathrm{~K}$ excretion for the Cork groups is similar to values for the Cambridgeshire study, but slightly higher than those obtained in the Scottish Heart Health Study and in the three UK centres for the Intersalt Study (Table 3).

The contribution of different food groups to $\mathrm{K}$ intake in Ireland and the UK is outlined in Table 4. The fruit and vegetable and dairy groups are the major dietary sources of $\mathrm{K}$. Dietary recommendations for increased $\mathrm{K}$ intake by the general population (Food Advisory Committee, $1984 a, b$ ) should, therefore, emphasize both these food groups. While increased intake of fruits and vegetables as a general recommendation is widely promoted (National Advisory Committee on Nutrition Education, 1983; Food Advisory Committee, $1984 a, b)$ recommendations on dairy products must be qualified so as not to conflict with guidelines for reduced fat intake. Thus, increased intake of reduced-fat dairy products (e.g. semi-skimmed milk) may be recommended as a measure to increase average $\mathrm{K}$ intake in the population. Given the importance of milk as a source of many essential nutrients in the Irish diet (Upton \& Gibney, 1987), this may have other benefits for the average diet.

\section{HEALTH SIGNIFICANCE OF DIETARY Na AND K}

While $\mathrm{Na}$ and $\mathrm{K}$ are both essential nutrients and serve many important physiological functions, the effect of these electrolytes on blood pressure has attracted most attention 
in terms of public health (Altschul et al. 1984). Hypertension is a common problem in many populations and is a major risk factor for stroke and coronary heart disease (World Health Organization, 1982). There is considerable evidence from epidemiological studies, clinical trials and animal studies that increasing $\mathrm{K}$ intake is associated with decreasing blood pressure (Langford, 1983; Tannen, 1983). This association has been confirmed within populations in two large recent studies of electrolyte excretion and blood pressure (Intersalt Cooperative Research Group, 1988; Smith et al. 1988). However, estimates of the strength of this association in the Intersalt Study indicate that the effect of a significant increase in average $\mathrm{K}$ intake of the population on mean population blood pressure would be small (about $4.5 \mathrm{~mm} \mathrm{Hg}$ decrease in systolic pressure per $100 \mathrm{mmol}$ increase in $\mathrm{K}$ ). Thus, increasing the daily $\mathrm{K}$ intake of a population by $25 \%$, e.g. from 70 to $87.5 \mathrm{mmol}$ would be equivalent to a reduction of only about 0.8 $\mathrm{mm} \mathrm{Hg}$ in mean systolic blood pressure. Thus, dietary guidelines for increased $\mathrm{K}$ intake by the general population (Food Advisory Committee, 1984b) cannot be justified entirely on the basis of a potential reduction in mean population blood pressure. However, guidelines which promote increased intake of fruit and vegetables and low-fat dairy products are consistent with an increase in $\mathrm{K}$ intake and may be justified on other public health grounds.

The relationship between $\mathrm{Na}$ and blood pressure has been debated since the last century (Porter, 1983), but despite many studies the issue remains unresolved. While the idea that high salt intake is a major determinant of increased blood pressure is now deep-rooted among many doctors and members of the public, the evidence for this is weak. Two of the reports which have been most influential in establishing this idea (Dahl, 1972; Glieberman, 1973) are based on a small number of often unreliable findings on $\mathrm{Na}$ intakes and blood pressures of different populations. Findings from two large recent studies (Intersalt Cooperative Research Group, 1988; Smith et al. 1988) show that the relationship between $\mathrm{Na}$ intake and blood pressure within populations is, at best, weak. It can be estimated from the Intersalt Study that, assuming Na intake to be causal, the effect of a large reduction in mean $\mathrm{Na}$ intake of a population on mean population blood pressure would be small (about $2.2 \mathrm{~mm} \mathrm{Hg}$ decrease in systolic pressure per 100 $\mathrm{mmol} \mathrm{Na}$ ). Thus, decreasing mean daily $\mathrm{Na}$ intake of a population by $25 \%$ (e.g. from 150 to $112.5 \mathrm{mmol}$ ) would be equivalent to a reduction of only about $0.8 \mathrm{~mm} \mathrm{Hg}$ in mean systolic pressure.

While the rise in blood pressure with age was more strongly related than blood pressure to urinary Na excretion (Intersalt Cooperative Research Group, 1988), it can be estimated that a $25 \%$ decrease in mean Na intake would be associated with a smaller rise in mean population blood pressure from age 25 to 55 years by only about $3.4 \mathrm{~mm} \mathrm{Hg}$ systolic and about $1.7 \mathrm{~mm} \mathrm{Hg}$ diastolic.

Thus, dietary guidelines for a reduction in $\mathrm{Na}$ intake by the general population which have been widely promulgated (National Advisory Committee on Nutrition Education, 1983; Department of Health and Social Security, 1984; Food Advisory Committee, $1984 a, b ;)$ are difficult to justify entirely on the basis of a potential reduction in mean population blood pressure.

Other potential benefits of a reduction in $\mathrm{Na}$ intake in the population have been proposed, but the evidence for these is incomplete at this time. Epidemiological evidence of a possible relationship between $\mathrm{Na}$ intake and stomach cancer has been presented in a number of studies (Joossens \& Geboers, 1981, 1987; Tuomilheto et al. 1984). 
There is also growing interest in a possible relationship between $\mathrm{Na}$ intake and osteoporosis. This is based on the observation that increased $\mathrm{Na}$ intake leads to increased urinary excretion of calcium (McCarron et al. 1981; Sabto et al. 1984; Castenmiller et al. 1985; Shortt et al. 1988b). Furthermore, there is also evidence that individuals differ in their susceptibility to increasing $\mathrm{Na}$ intake; with increasing $\mathrm{Na}$ an increase in urinary $\mathrm{Ca}$ is not evident in some individuals, while increases of variable size are seen in others (Shortt et al. 1988b). In rats high salt intake leads to increased urinary Ca excretion and bone loss (Goulding \& Gold, 1986; Shortt et al. 1987b). However, whether the $\mathrm{Na}$-induced urinary $\mathrm{Ca}$ loss results in increased $\mathrm{Ca}$ requirements or contributes to bone loss in humans are important questions which have yet to be answered.

Thus, on the basis of present evidence there is a weak case for recommending a reduction in $\mathrm{Na}$ intake for the general population, either on grounds of potential benefits for blood pressure or on other grounds.

It is important to distinguish between dictary guidelines for the general population and dietary advice for individuals who may be at 'high risk', e.g. hypertensive patients. Increased dietary $\mathrm{K}$ and reduced dietary $\mathrm{Na}$ intake should be recommended for these on the basis of the reduction in blood pressure achieved by such dietary changes in some hypertensives in clinical trials (McGregor et al. 1982; Grobbee \& Hofman, 1986).

\section{REFERENCES}

Altschul, A. M., McPherson, R. A. \& Burriss, J. F. (1984). Dietary sodium, the ratio of $\mathrm{Na}^{+} / \mathrm{K}^{+}$and essential hypertension. Nutrition Abstracts and Reviens 54, 823-844.

Bingham, S. \& Cummings, J. H. (1983). The use of 4-amino-benzoic acid as a marker to validate the completeness of $24 \mathrm{~h}$ urine collections in man. Clinical Science 64, 629-635.

Bingham, S. \& Cummings, J. H. (1985). The usc of creatininc output as a check on the completeness of 24-h urine collections. Human Nutrition: Clinical Nutrition 39C, 343-353.

Bingham, S. A., Williams, R., Cole, T. A., Price. C. P. \& Cummings. J. H. (1988). Reference values for analytes of 24-h urine collections known to be complete. Annals of Clinical Biochemistry 25, $610-619$.

Bleiler, R. E. \& Schedl, H. P. (1972). Creatinine excretion: variability and relationships to diet and body size. Journal of Laboratory Clinical Medicine 59, 945-955.

Bull, N. L. \& Buss, D. H. (1980a). Contributions of foods to sodium intakes. Proceedings of the Nutrition Society 39, 30A.

Bull, N. L. \& Buss, D. H. (1980b). Contributions of foods to potassium intakes. Proceedings of the Nutrition Society 39, 31A.

Castenmiller, J., Mensink, R., Van der Heyden, L., Kouwenhoven, T., Hautvast. J. G. A. G., de Leeuw, P. \& Schaafsma, G. (1985). The effect of dietary sodium on urinary calcium and potassium excretion in normotensive men with different calcium intakes. American Journal of Clinical Nutrition 41, 52-60.

Central Statistics Office (1982). Household Budget Statistics Survey, 1980, vol. 1. p. 105. Dublin: Stationery Office.

Connolly, J. F., Kevany, J. P., Brady, L. B., Stewart, D. \& Harrington, D. (1980). Dictary biochemical and anthropometric effects of dairy products on selected family groups. Irish Journal of Food Science and Technology 4, 143-172.

Dahl, L. K. (1972). Salt and hypertension. American Journal of Clinical Nutrition 25, 231-244.

Department of Health and Social Security (1984). Diet and Cardiovascular Disease. Committee on Medical Aspects of Food Policy, Report on Health and Social Subjects no. 28. Londion: H.M. Stationery Office.

Downey, G., Connolly, J. F. \& Higgins, I. (1982). Contribution of bread to daily nutricnt intake by volunteer family groups in the Republic of Ircland. Irish Journal of Food Science and Technology 6, 117-134.

Flynn, A. (1984). Determination of salt intake of individuals in epidemiological studies. In Individual Susceptibility to Salt Intake and Arterial Hypertension. FURONUT Report no. 3, pp. 19-24 [S. Ghione, editor]. Wageningen: Stichtung Netherlands Instituut voor de Voeding.

Folin, D. (1905). Laws governing the chemical composition of urine. American Journal of Physiology 13, 66-115. 
Food Advisory Committee (1984a). Report on Public Health Policy on Diet and Heart Disease. Dublin: Department of Health.

Food Advisory Committee (1984b). Guidelines for Preparing Information and Advice to the General Public on Healthy Eating. Dublin: Department of Health.

Fuller, N. J. \& Elia, M. (1988). Factors influencing the production of creatinine: implications for the dctermination and interpretation of urinary creatinine in man. Clinica Chimica Acta 175, 199-210.

Glicberman, L. (1973). Blood pressure and dietary salt in human populations. Ecology of Food and Nutrition 2, 143-156.

Goulding, A. \& Gold, E. (1986). Effects of dietary sodium chloride loading on parathyroid function, 1,25 ,-dihydroxyvitamin D, calcium balance and bone metabolism in female rats during chronic prednisolone administration. Endocrinology 119, 2148-2154.

Grobbee, D. E. \& Hofman, A. (1986). Does sodium restriction lower blood pressure? British Medical Journal 293, 27-29.

Heymsfield, S. B., Arteaga, C., McManus, C., Smith, J. \& Moffitt, S. (1983). Measurement of muscle mass in humans: validity of the 24-h urinary creatinine method. American Journal of Clinical Nutrition 37, $478-494$.

Institute of Food Technologists (1980). Dietary salt: a scientific status summary by the Institute of Food Technologists' Expert Panel on Food Safety and Nutrition and the Committee on Public Information. Food Technology January, 85-91.

Intersalt Cooperative Research Group (1988). Intersalt: an international study of electrolyte excretion and blood pressure. Results for 24 hour urinary sodium and potassium excretion. British Medical Journal 297, 319-328.

James, W. P. T. Ralph, A. \& Sanchez-Castillo, C. P. (1987). The dominance of salt in manufactured food in the sodium intake of affluent societies. Lancet $\mathbf{i}, 426-429$.

Joossens, J. V., Claessens, J., Gebocrs, J. \& Clacs, J. H. (1980). Electrolytes and creatinine in multiple 24 h urine collections 1970-1974. In Epidemiology of Arterial Blood Pressure, pp. 45-63. [H. Kestleoot and J. V. Joossens, editors]. Den Haag. The Netherlands: Martinus Nijhoff Publishers.

Joossens, J. V. \& Geboers, J. (1981). Nutrition and gastric cancer. Nutrition and Cancer 2, $250-261$.

Joossens, J. V. \& Geboers, J. (1984). Monitoring salt intake of the population: methodological considerations. In Surveillance of Dietary Habits of the Population With Regard to Cardiovascular Diseases. EURONUT Report no. 2, pp. 61-73 [G. G. de Backer, H. Tunstall-Pedoe and P. Ducimetiere, editors]. Wageningen, The Netherlands: Department of Human Nutrition, Agricultural University.

Joossens, J. V. \& Geboers, J. (1987). Dietary salt and risks to health. American Journal of Clinical Nutrition 45. $1277-1288$.

Knuiman, J. T., Hautvast, J. G. A. G., Van der Heyden, L., Geboers, J., Joossens, J. V., Tornquist, H., Isaksson, B., Pietinen, P., Tuomilheto, J., Flynn, A., Shortt, C., Boing, H., Yomtov, B., Angelico, F. \& Ricci, G. (1986a). A multi-centre study on within-person variability in the urinary excretion of sodium. potassium, calcium and creatinine in 8 European centres. Human Nutrition: Clinical Nutrition 40C, $343-348$

Knuiman, J. T., Hautvast, J. G. A. G., Van der Heyden, L., Geboers, J., Joossens, J. V., Tornquist, H., Isaksson, B., Pietinen, P., Tuomilheto, J., Poulsen, L., Flynn, A., Shortt, C., Boing. H., Yomtov, B., Magalhes, E., Angelico, F., Stefanutti, C., Fazio, S., Cantini, R., Ricci, G., Trichopoulou, A. \& Katapoti, Z. (1986b). A multi-centre study on completeness of urine collection in 11 European countries. 1. Some problems with the use of creatinine and 4-amino benzoic acid as markers of completeness of collection. Human Nutrition: Clinical Nutrition 40C, 229-237.

Langford, H. G. (1983). Dietary potassium and hypertension: epidemiological data. Annals of Internal Medicine 98, 770-772.

Liu, K., Cooper, R., McKeever, J., McKeever, P.. Byington, R., Solters, L. Stamler, R., Gosch, F., Stevens, E. \& Stamler, J. (1979). Assessment of the association between habitual salt intake and high blood pressure - methodological problems. American Journal of Epidemiology 110, 219-226.

McCarron, D. A., Rankin, L. I., Bennett, W. M., Krutzik, S., McClung, M. R. \& Luft. F. C. (1981). Urinary calcium excretion at extremes of sodium intake in normal man. American Journal of Nephrology 1, 84-90.

McGregor, G. A.. Smith, S. J., Markandu, N. D., Banks, R. A. \& Sagnella, G. A. (1982). Moderate potassium supplementation in essential hypertension. Lancet ii, 567-570.

Madden, A., Flynn, A. \& Cremin, F. M. (1983). Relationship between dietary sodium intake and urinary calcium excretion. In Research in Food Science and Nutrition, vol. 3, pp. 30-31 [J. V. McLoughlin and B. M. McKenna, editors]. Dublin: Boole Press. 
Mathers, J. C. (1988). Reduction in sodium chloride intake: effects on urinary Na, $\mathrm{K}$ and aldosterone output in healthy frec-living adults. Journal of Human Nutrition and Dietetics 1, 155-161.

National Advisory Committee on Nutrition Education (1983). Proposals for Nutritional Guidelines for Health Education in Britain. London: Health Education Council.

Paul, A. A. \& Southgate. D. A. T. (1978). McCance and Widdowson's The Composition of Foods. London: H.M. Stationery Office.

Porter, G. A. (1983). Chronology of the sodium hypothesis and hypertension. Annals of Internal Medicine 98 , 720-723.

Sabto, J., Powell, M. J., Breidahl, M. J. \& Gurr, F. W. (1984). Influence of urinary sodium on calcium excretion in normal individuals. Medical Journal of Australia 140, 354-356.

Sanchez-Castillo, C. P., Warrender, S., Whitehead, T. P. \& James, W. P. T. (1987). An assessment of the sources of dietary sait in a British population. Clinical Science 72, 95-102.

Schachter, J., Harper, P. H., Radin, M. E., Caggiula, A. W., McDonald, R. H. \& Diven, W. F. (1980). Comparison of sodium and potassium intake with excretion. Hypertension 2, 695-699.

Shortt, C., Flynn, A. \& Morrissey, P. A. (1987a). A study of the intake of sodium and potassium in a selected population sample of males and females in Ireland. Irish Journal of Food Science and Technology 11, 35-42.

Short, C., Flynn, A. \& Morrissey, P. A. (1987b). Effect of dietary sodium chloride supplements on mineral metabolism in the rat. Irish Journal of Food Science and Technology 11, 186.

Shortt, C., Flynn, A. \& Morrissey, P. A. (1988a). Assessment of sodium and potassium intakes. European Journal of Clinical Nutrition 42, 605-609.

Shortt, C., Madden, A., Flynn, A. \& Morrissey, P. A. (1988b). Influence of dietary sodium intake on urinary calcium excretion. European Journal of Clinical Nutrition 42, 595-603.

Smith, W. C. S., Crombie, I. K., Tavendale, R. T.. Gulland, S. K. \& Tunstall-Pedoe, H. D. (1988). Urinary electrolyte excretion, alcohol consumption and blood pressure in the Scottish Heart Health Study. British Medical Journal 297, 229-230.

Tannen, R. L. (1983). Effects of potassium on blood pressure control. Annals of Internal Medicine 98, 773-780.

Toumilheto, J., Geboers, J., Joossens. J. V., Salonen, J. T. \& Tanshanen, A. (1984). Trends in stomach cancer and stroke in Finland. Comparison to Northwest Europe and U.S.A. Stroke 15, 823-828.

Upton, P. K. \& Gibney, M. J. (1977). The Irish diet: a comparison of nutrient intakes for urban and rural households. Irish Journal of Food Science and Technology 1, 79-85.

Upton, P. K. \& Gibney, M. J. (1987). Nutrient intakes in Ireland in 1980: estimates derived from household expenditure on food. Irish Journal of Medical Science 56, 83-89.

Van Staveren, W. A., Hautvast, J. G. A. G., Katan, M. B., Van Montfort. M. A. \& Van Oosten-Van der Goes, H. G. (1982). Dietary fibre consumption in an adult Dutch population. Journal of the American Dietetic Association 80, 324-330.

Williams, D. R. R. \& Bingham, S. A. (1986). Sodium and potassium intakes in a representative population sample: estimation from 24 -h urine collections known to be complete in a Cambridgeshire village. British Journal of Nutrition 55, 13-22.

World Health Organization (1982). Prevention of Coronary Heart Disease. Technical Report Series no. 678. Geneva: World Health Organization. 